\title{
Species Subgroup
}

National Cancer Institute

\section{Source}

National Cancer Institute. Species Subgroup. NCI Thesaurus. Code C62691.

A taxonomic category below species group. 